\title{
Constraining fault interpretation through tomographic velocity gradients: application to northern Cascadia
}

\author{
K. Ramachandran \\ Department of Geosciences, The University of Tulsa, Tulsa, Oklahoma, USA \\ Correspondence to: K. Ramachandran (kr@utulsa.edu) \\ Received: 17 September 2011 - Published in Solid Earth Discuss.: 28 September 2011 \\ Revised: 6 February 2012 - Accepted: 12 February 2012 - Published: 16 February 2012
}

\begin{abstract}
Spatial gradients of tomographic velocities are seldom used in interpretation of subsurface fault structures. This study shows that spatial velocity gradients can be used effectively in identifying subsurface discontinuities in the horizontal and vertical directions. Three-dimensional velocity models constructed through tomographic inversion of active source and/or earthquake traveltime data are generally built from an initial 1-D velocity model that varies only with depth. Regularized tomographic inversion algorithms impose constraints on the roughness of the model that help to stabilize the inversion process. Final velocity models obtained from regularized tomographic inversions have smooth three-dimensional structures that are required by the data. Final velocity models are usually analyzed and interpreted either as a perturbation velocity model or as an absolute velocity model. Compared to perturbation velocity model, absolute velocity models have an advantage of providing constraints on lithology. Both velocity models lack the ability to provide sharp constraints on subsurface faults. An interpretational approach utilizing spatial velocity gradients applied to northern Cascadia shows that subsurface faults that are not clearly interpretable from velocity model plots can be identified by sharp contrasts in velocity gradient plots. This interpretation resulted in inferring the locations of the Tacoma, Seattle, Southern Whidbey Island, and Darrington Devil's Mountain faults much more clearly. The Coast Range Boundary fault, previously hypothesized on the basis of sedimentological and tectonic observations, is inferred clearly from the gradient plots. Many of the fault locations imaged from gradient data correlate with earthquake hypocenters, indicating their seismogenic nature.
\end{abstract}

\section{Introduction}

Controlled source and earthquake traveltime data are commonly used for construction of tomographic velocity models for mapping crustal structure. Local and regional tomography models obtained from inversion of the traveltime data are useful in interpretation of lithology and subsurface structure. Subsurface structures that can be mapped by tomographic velocities are generally due to varying lithology across a fault, lithology difference across basin margins and basement surfaces, and varying compaction in rocks across the fault surfaces within sedimentary units. Even though these contact/fault surfaces are in general sharp transitions in the subsurface, tomographic velocity models depict these surfaces by smooth velocity variation. This is due to the fact that the velocity models are constructed by applying smoothing constraints to overcome the ill-conditioned nature of the tomographic inverse problem. Spatial gradients of the tomographic velocity model are seldom used in interpreting the velocity model. The only article that has explicitly addressed the issue of interpreting tomography velocity gradients is by Fishwick (2006).

Results from an investigation of the applicability of velocity gradient analysis for structural interpretation of the upper crust, conducted using a previously constructed regional 3-D tomographic P-wave velocity model for the northern Cascadia subduction zone (Ramachandran et al., 2006) are presented in this article. Information from horizontal gradients in $\mathrm{X}$ (east-west) and $\mathrm{Y}$ (north-south) directions define structural contacts much more clearly than the tomographic velocity model. Some of the structural contacts identified from velocity gradient plots show correlation with relocated earthquake positions. This correlation is not obvious in the 
velocity plots. The gradient in the $\mathrm{Z}$ (depth) direction also shows correlation with earthquake clusters at some fault locations much more clearly than the velocity plots.

\section{Data and methods}

\subsection{Tomography}

First arrival traveltime tomography using controlled source data from Seismic Hazards Investigation in Puget Sound (SHIPS) and regional earthquake data from British Columbia, Canada and Washington State, USA resulted in a detailed velocity model for the northern Cascadia subduction zone (Ramachandran et al., 2006). Approximately 150000 controlled source traveltime picks and 70000 traveltime picks from nearly 3000 earthquakes were employed in constructing this velocity model. Traveltime data acquired in a three-dimensional experiment contain information about the spatial velocity structure in the subsurface. Even though minimum structure models implementing smoothness constraints are developed through tomographic inversion, structures which are needed to satisfy observed data are developed in the velocity model during regularized inversion. The smoothness constraints applied in the regularized tomographic inversion method are discussed in Ramachandran et al. (2005) and references therein. The smoothness constraints implemented in the inversion resulted in a final velocity model that has four times more smoothing in the horizontal direction than in the vertical direction. The starting model for the inversion is a 1-D model that has variations only in the $\mathrm{Z}$ direction. Velocity reversals with depth were not used in the starting 1-D model. Velocity reversals with depth present in the final model are required by the data.

\subsection{Velocity gradient computation}

The origin of the 3-D velocity model is at the top of the model in the northwest corner. Gradients of velocity in X, $\mathrm{Y}$, and $\mathrm{Z}$ directions are computed using adjacent values in respective directions. Describing the velocity model in three dimensions by $V(i, j, k)$, indices $\mathrm{i}, \mathrm{j}$ and $\mathrm{k}$ corresponding to velocity node positions in $\mathrm{X}, \mathrm{Y}$ and $\mathrm{Z}$ directions, the velocity gradients are computed as below:

$V_{\mathrm{x}}=[V(i+1, j, k)-V(i, j, k)] /$ node spacing,

$V_{\mathrm{y}}=[V(i, j+1, k)-V(i, j, k)] /$ node spacing,

$V_{\mathrm{z}}=[V(i, j, k+1)-V(i, j, k)] /$ node spacing.

A negative gradient in the $\mathrm{X}$ direction indicates a decrease in velocity from west to east and a negative gradient in the $\mathrm{Y}$ direction indicates a decrease in velocity from north to south. A negative gradient in the $\mathrm{Z}$ direction indicates a decrease in velocity with depth.

\section{Results}

In general, the Earth's upper crust shows much lateral variation in composition and structure. Lateral variations in the upper crustal regions due to faulting and basin boundaries are mapped using plots of horizontal gradients of tomographic velocity model. Vertical gradients of tomographic velocity models are useful in identifying basement features. A practical case study using five vertical cross sections (profile locations in Fig. 1) extracted from the 3-D tomographic velocity model along with gradients in $\mathrm{X}, \mathrm{Y}$, and $\mathrm{Z}$ directions is used to illustrate the strength of this interpretational method. Profiles AB, CD, EF, and GH (Figs. 2, 3, 4, and 5) are approximately E-W trending and profile IJ (Fig. 6) is oriented SSW-NNE direction. Horizontal slices showing the tomographic velocity model and computed velocity gradients at three kilometer depth are shown in Fig. 7.

\subsection{Leech River fault}

The Metchosin Igneous Complex in southern Vancouver Island is the extreme northerly exposure of the Crescent Terrane, which includes the Crescent Formation and Coast Range Basalts of western Washington State and Oregon (Babcock et al., 1992). This complex dips approximately $30^{\circ}$ to the north-northeast (Massey, 1986) and is bounded to the north by the Leech River fault (Fig. 1), which separates it from the Pacific Rim and Wrangellia terranes. The Leech River fault has been imaged by seismic reflection as a thrust fault dipping $35^{\circ}-45^{\circ}$ to the northeast and extending to a depth of $10 \mathrm{~km}$ (Clowes et al., 1987).

The Leech River fault and the outline of the Metchosin Igneous Group in the near subsurface are identified on profiles AB (Fig. 2) and CD (Fig. 3). The Leech River fault that separates the Metchosin Igneous Complex rocks from Pacific Rim metasedimentary rocks is mapped at $60 \mathrm{~km}$ position on profile $\mathrm{AB}$ and at $80 \mathrm{~km}$ position on profile $\mathrm{CD}$ as sharp changes in the $\mathrm{X}$ and $\mathrm{Y}$ gradients. Since the profiles are oblique to the fault separating units with different velocities, the velocity gradient contrast at the profile-fault intersection is observed on both $\mathrm{X}$ and $\mathrm{Y}$ gradient plots. The contact of the Metchosin Igneous rocks with the sediments in the Strait of Juan de Fuca is identified on the $\mathrm{X}$ and $\mathrm{Y}$ gradients at $30 \mathrm{~km}$ location on profile $\mathrm{AB}$. The features discussed above are not interpretable as clearly from the velocity model plots alone.

\subsection{Outer Islands fault}

The Outer Islands fault is a large extensional fault that downdrops the Cretaceous sediments in the Watcom depocenter of the Georgia basin by $3 \mathrm{~km}$ below the Tertiary sediments (England and Bustin, 1998). At $150 \mathrm{~km}$ on profile AB (Fig. 2), the Outer Island fault is identified on the X, Y, and $\mathrm{Z}$ gradient plots. Younger sediments exhibit rapid increase 


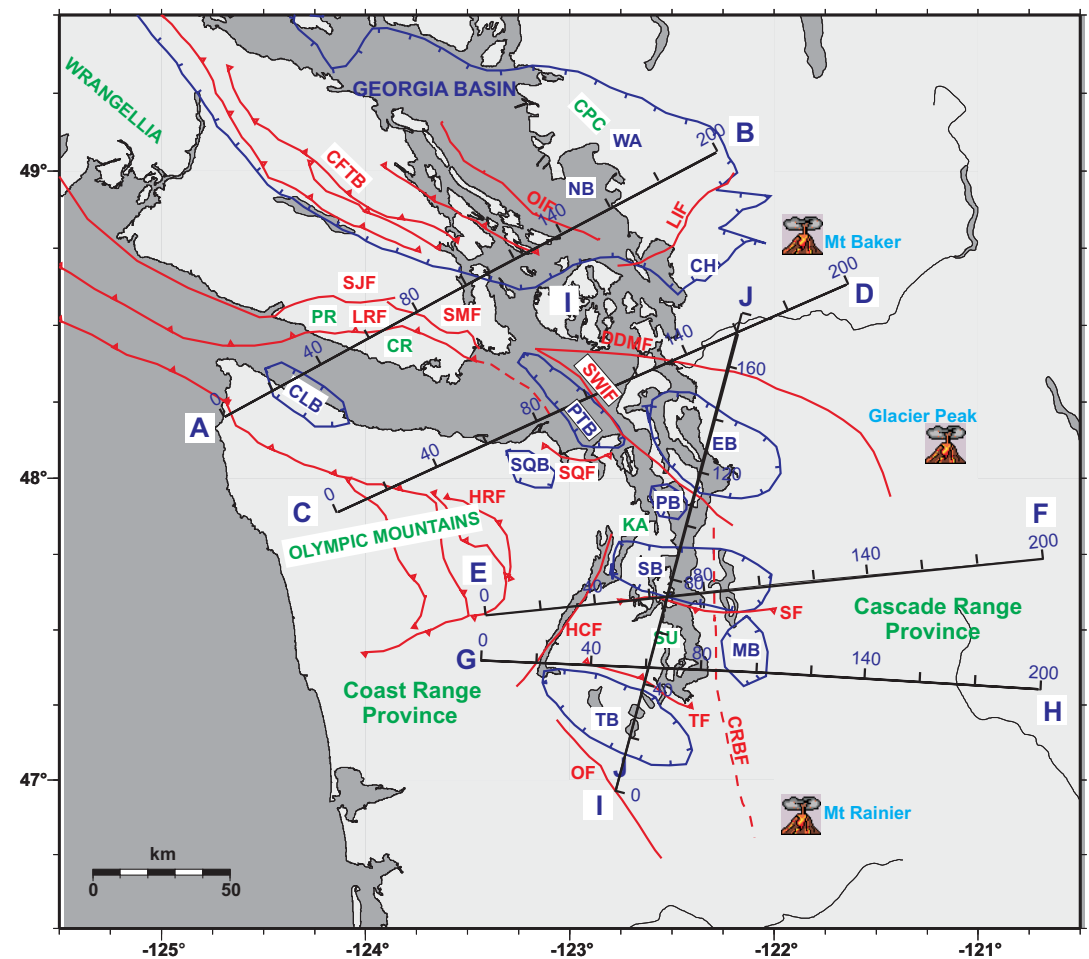

Fig. 1. Location map showing the study area. Vertical cross-sections of velocities and spatial gradients of velocities along profiles $A B$, CD, EF, GH and IJ are shown in Figs. 2-6. CFTB-Cowichan Fold and Thrust Belt; CH-Chuckanut sub-basin; CLB-Clallam basin; CPCCoast Plutonic Complex; CRBF-Coast Range boundary fault; CR-Crescent terrane; DDMF-Darrington-Devils Mountain fault; EB-Everett basin; HCF-Hood Canal fault; HRF-Hurricane Ridge fault; KA-Kingston Arch; LIF-Lummi Island fault; LRF-Leech River fault; MBMuckleshoot Basin; NB- Nanaimo sub-basin; OF-Olympia fault; OIF-Outer Islands fault; PB-Possesion Basin; PR-Pacific Rim terrane; PTB-Port Townsend basin; SB-Seattle basin; SF-Seattle fault; SJF-San Juan fault; SMF-Survey Mountain fault; SQB-Sequim basin; SQFSequim fault; SU-Seattle uplift; SWIF-southern Whidbey Island fault; TB-Tacoma basin; TF-Tacoma fault; WA-Whatcom sub-basin. Major geologic features taken from Muller (1977), England and Bustin (1998), Brocher et al. (2001), and Van Wagoner et al. (2002).

in velocity with depth due to compaction; this results in a constant or increasing gradient in such situations. On profile AB (Fig. 2), the sharp contact and increasing velocity gradients to the northeast in the $\mathrm{Z}$ gradient plot at $150 \mathrm{~km}$ location indicates that the younger sediments extend much deeper in the basin. In the horizontal slice plot of $\mathrm{Z}$ gradient (Fig. 7c), the fault location correlates with a sharp gradient change.

\subsection{Southern Whidbey Island fault}

Johnson et al. (1996) have described the Southern Whidbey Island fault (SWIF) (Fig. 1) as a broad (6-11 km) transpressional zone comprising three main splays. In this zone, the Eocene marine basaltic basement on the south and southwest is juxtaposed with heterogeneous pre-Tertiary basement in the northeast. The southern Whidbey Island fault is a potential seismogenic and tsunamigenic structure below the eastern Strait of Juan de Fuca (Johnson et al., 1996; Fisher et al., 2005; Sherrod et al., 2008). Holocene displacements have been documented on the SWIF; Kelsey et al. (2004) noted a possible tsunami deposit for the most recent paleoearthquake.
On profile CD (Fig. 3), between 95 and $105 \mathrm{~km}$ location, the Southern Whidbey Island fault zone is identified on $\mathrm{X}$ and $\mathrm{Y}$ gradient plots as sharp contrasts. At $105 \mathrm{~km}$ the $\mathrm{X}$ and $\mathrm{Y}$ gradient discontinuities coincide with a line of earthquake hypocenters, indicating that this is an active fault. On the SW-NE oriented profile IJ (Fig. 6), SWIF can be seen in the $\mathrm{Y}$ gradient plot at $110 \mathrm{~km}$ location.

\subsection{Darrington-Devils Mountain fault}

Near the eastern strait of Juan de Fuca, the Darrington-Devils Mountain fault (DDMF) strikes nearly east-west from the Cascade Range to Vancouver Island (Fig. 1), dips $45^{\circ}-75^{\circ}$ to the north, and forms the northern boundary of the onshore Everett Basin. This fault is active as indicated by highresolution seismic reflection sections, which show that Quaternary strata are faulted and/or folded (Johnson et al., 2001).

This fault is identified on profile CD (Fig. 3), at $140 \mathrm{~km}$ location on the $\mathrm{X}$ and $\mathrm{Y}$ gradient plots; the signature of this fault is not visible in the velocity plot. On the SW-NE oriented profile IJ (Fig. 6), the Y gradient plot shows the 

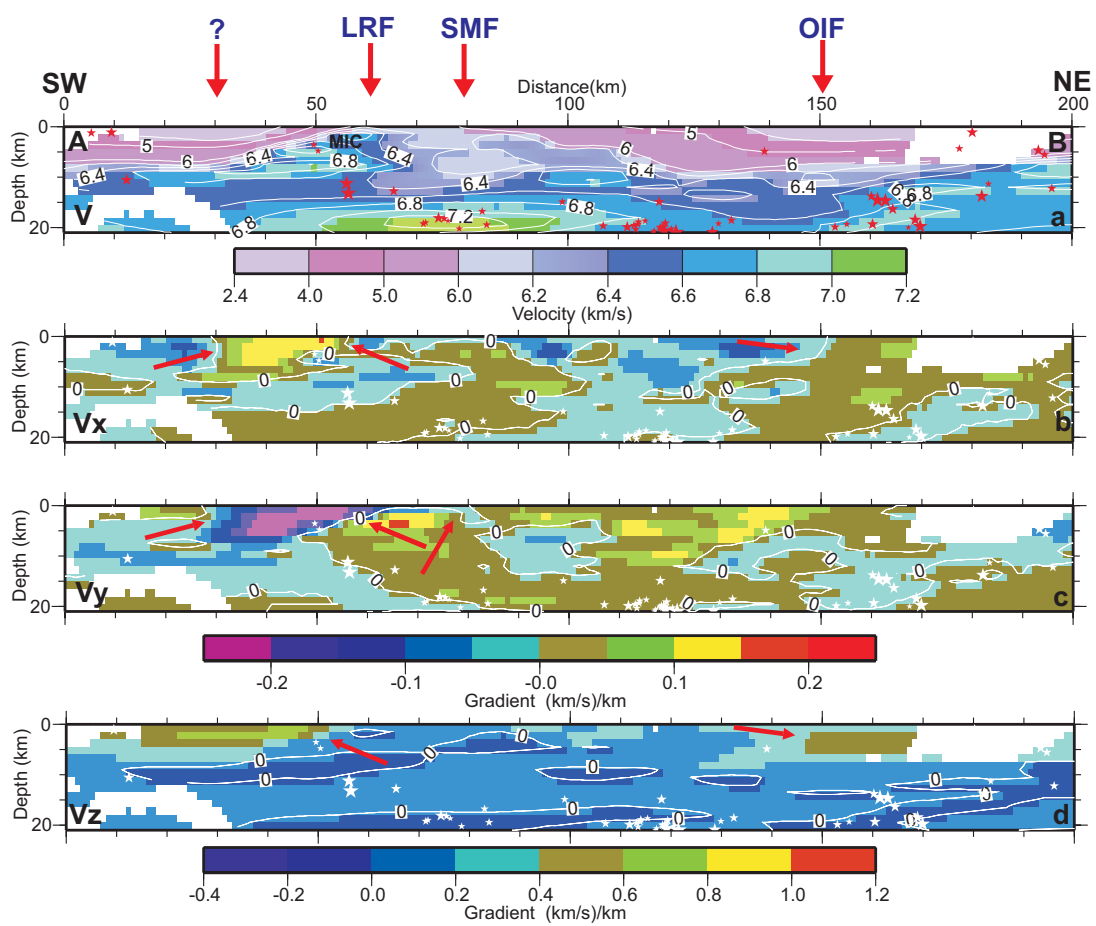

Fig. 2. Profile AB. Vertical cross-section of (a) tomographic velocity model (b) X gradient of velocity model, (c) Y gradient of velocity model, and (d) Z gradient of velocity model. MIC - Metchosin Igneous Complex. Abbreviations as in Fig. 1.

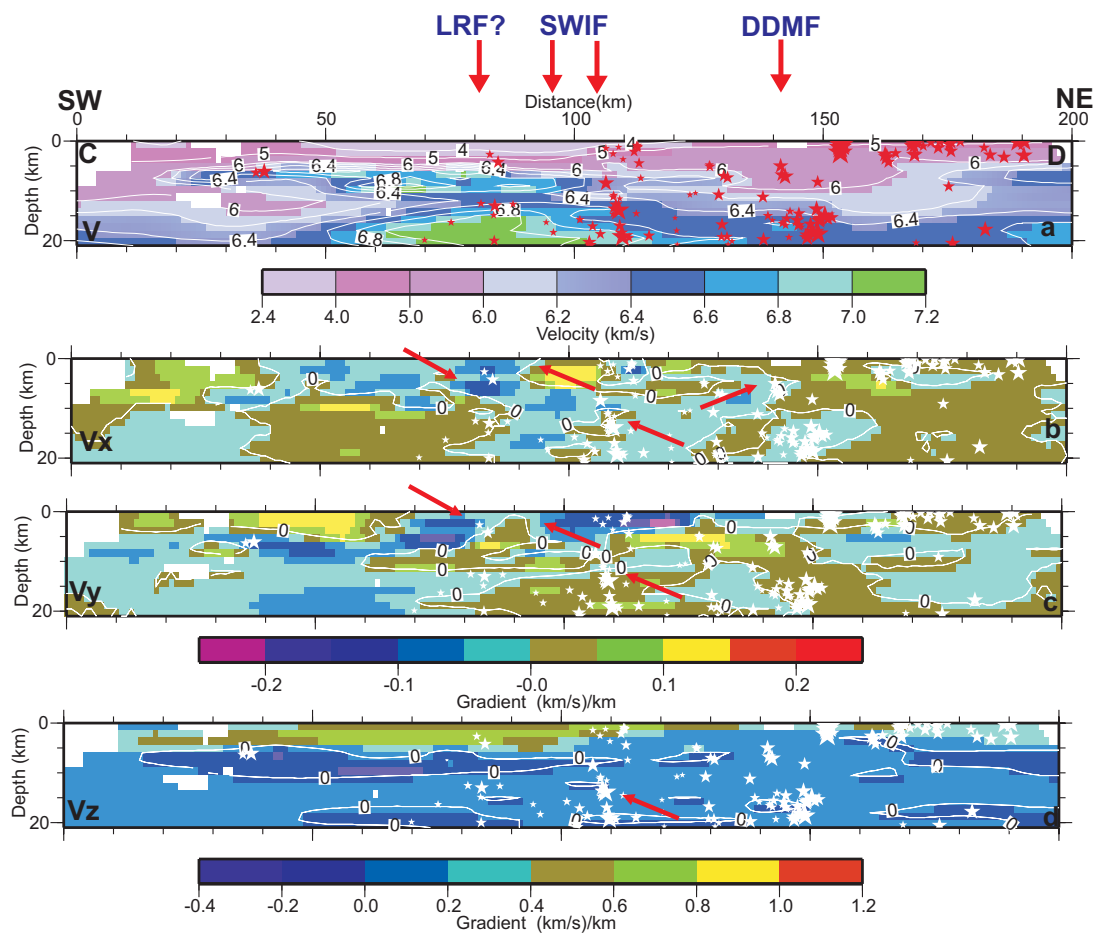

Fig. 3. Profile CD. Vertical cross-section of (a) tomographic velocity model (b) X gradient of velocity model, (c) Y gradient of velocity model, and (d) Z gradient of velocity model. Abbreviations as in Fig. 1. 


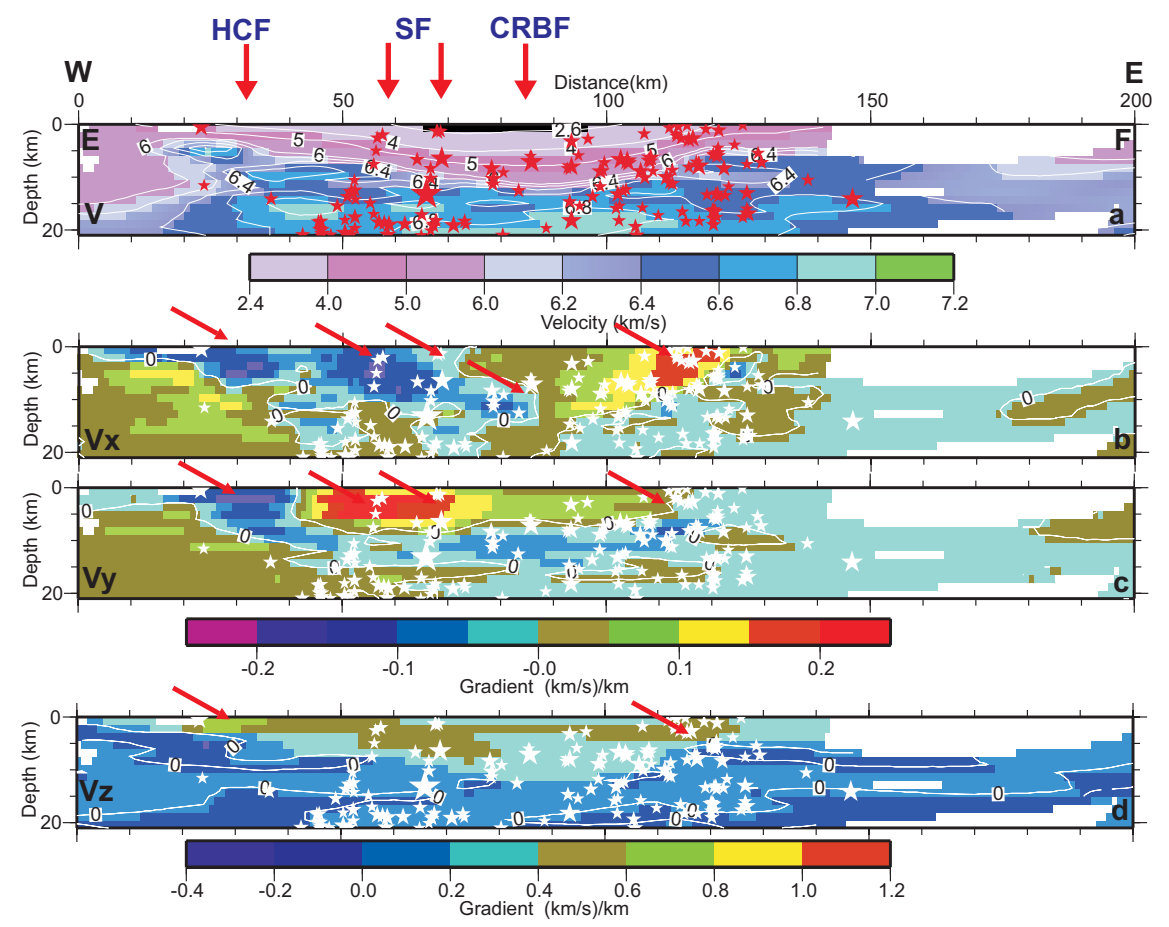

Fig. 4. Profile EF. Vertical cross-section of (a) tomographic velocity model (b) X gradient of velocity model, (c) Y gradient of velocity model, and (d) $\mathrm{Z}$ gradient of velocity model. Abbreviations as in Fig. 1.

signature of DDMF at $160 \mathrm{~km}$ location in terms of varying gradients across the fault, correlating with earthquake locations. In the horizontal slice plot of Y gradient (Fig. 7d), the fault location correlates with a sharp gradient change in the $\mathrm{N}-\mathrm{S}$ direction.

\subsection{Hood Canal fault}

Based on surface geology, gravity data and limited magnetic observations, Danes et al. (1965) concluded that an unnamed, major active fault separates the Puget Lowlands from the Olympic Mountains and noted that northern Hood Canal developed along this fault. The Hood Canal fault zone (Fig. 1) is a northerly trending feature that is defined largely by geophysical anomalies and seismic-reflection data that collectively suggest a major active fault zone (e.g. Brocher et al., 2001; Dragovich et al., 2002; Blakely et al., 2002).

On profile EF (Fig. 4), the Hood Canal fault appears as a smooth transition at $30 \mathrm{~km}$ location in the velocity model. However, this fault can be identified by sharper discontinuities on the $\mathrm{X}, \mathrm{Y}$, and $\mathrm{Z}$ gradient plots at approximately $30 \mathrm{~km}$ location. To the south, this fault can be identified on profile $\mathrm{GH}$ (Fig. 5) at $20 \mathrm{~km}$ location on the $\mathrm{X}$ and $\mathrm{Y}$ gradient plots. In the horizontal slice plot of X, Y, and Z gradients (Fig. 7), the fault location correlates with a sharp gradient change.

\subsection{Seattle fault}

In Puget Lowland, the Seattle basin is bounded to the south by the Seattle fault zone (Fig. 1). The Seattle fault zone is made up of several east-west trending fault segments (e.g. Johnson et al., 1994; Pratt et al., 1997; Wells et al., 1998). South of the Seattle fault, Crescent basement lies close to the surface (e.g. Pratt et al., 1997). Reverse displacement on the Seattle fault has resulted in both subsidence of the Seattle basin north of the fault and uplift of the basement south of the fault (Johnson et al., 1994, 1999; Pratt et al., 1997). Holocene seismicity and tsunamigenesis have been documented on the Seattle fault (e.g. Atwater and Moore, 1992).

On profile IJ (Fig. 6), the Seattle fault zone is inferred between 65 and $75 \mathrm{~km}$ location on the $\mathrm{Y}$ and $\mathrm{Z}$ gradient plots. The $\mathrm{Z}$ gradient plot has a sharp discontinuity at about $75 \mathrm{~km}$ location on this profile, coinciding with a near vertical location of earthquake hypocenters. Such a sharp feature is not readily visible in the velocity plot. North of this location, the $\mathrm{Z}$ gradient map shows higher gradients extending deeper; this indicates that the sedimentary column extends probably down to $10 \mathrm{~km}$ depth. In the horizontal slice plot of $\mathrm{Z}$ and $\mathrm{Y}$ gradients (Fig. 7c and d), the fault location correlates with a sharp gradient change in the $\mathrm{N}-\mathrm{S}$ direction. 


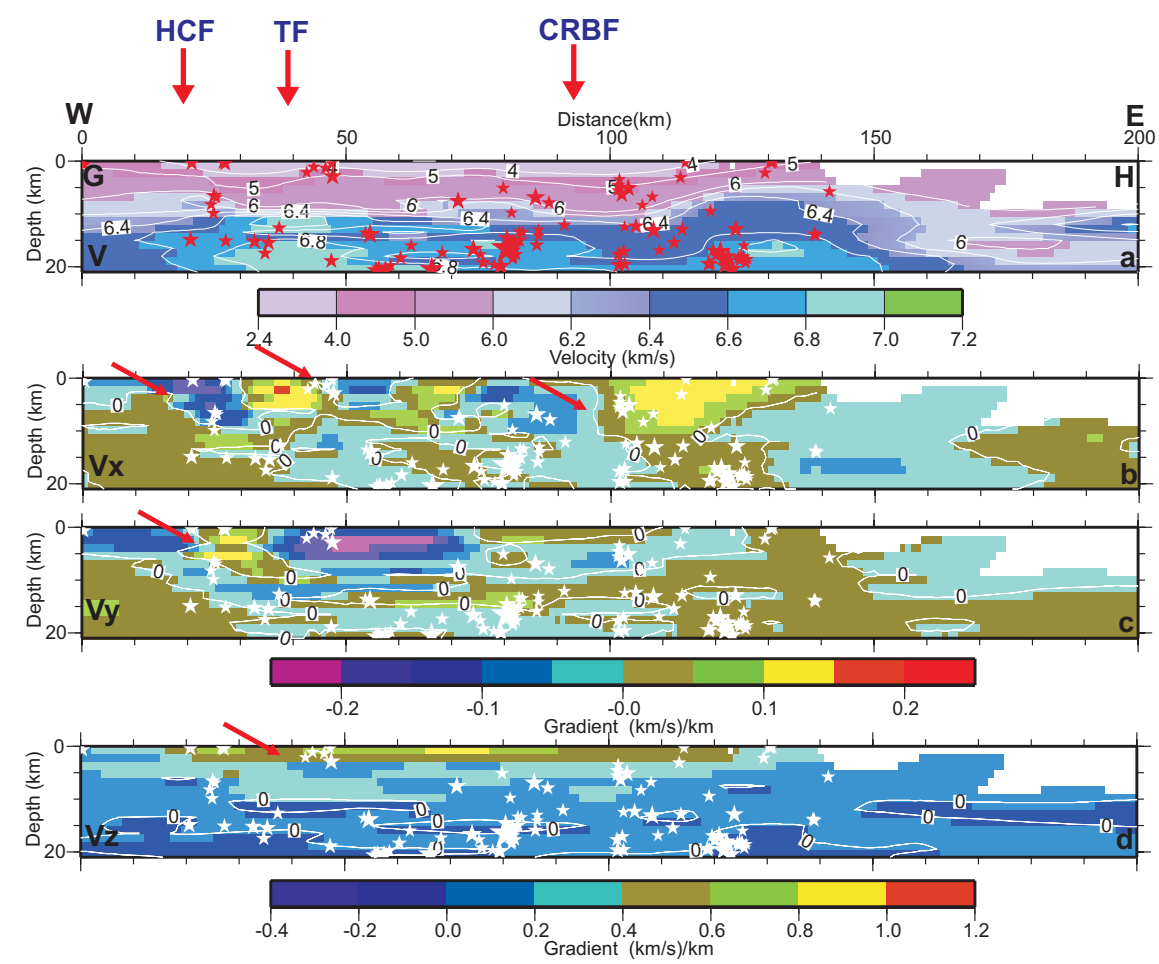

Fig. 5. Profile GH. Vertical cross-section of (a) tomographic velocity model (b) X gradient of velocity model, (c) Y gradient of velocity model, and (d) $\mathrm{Z}$ gradient of velocity model. Abbreviations as in Fig. 1.
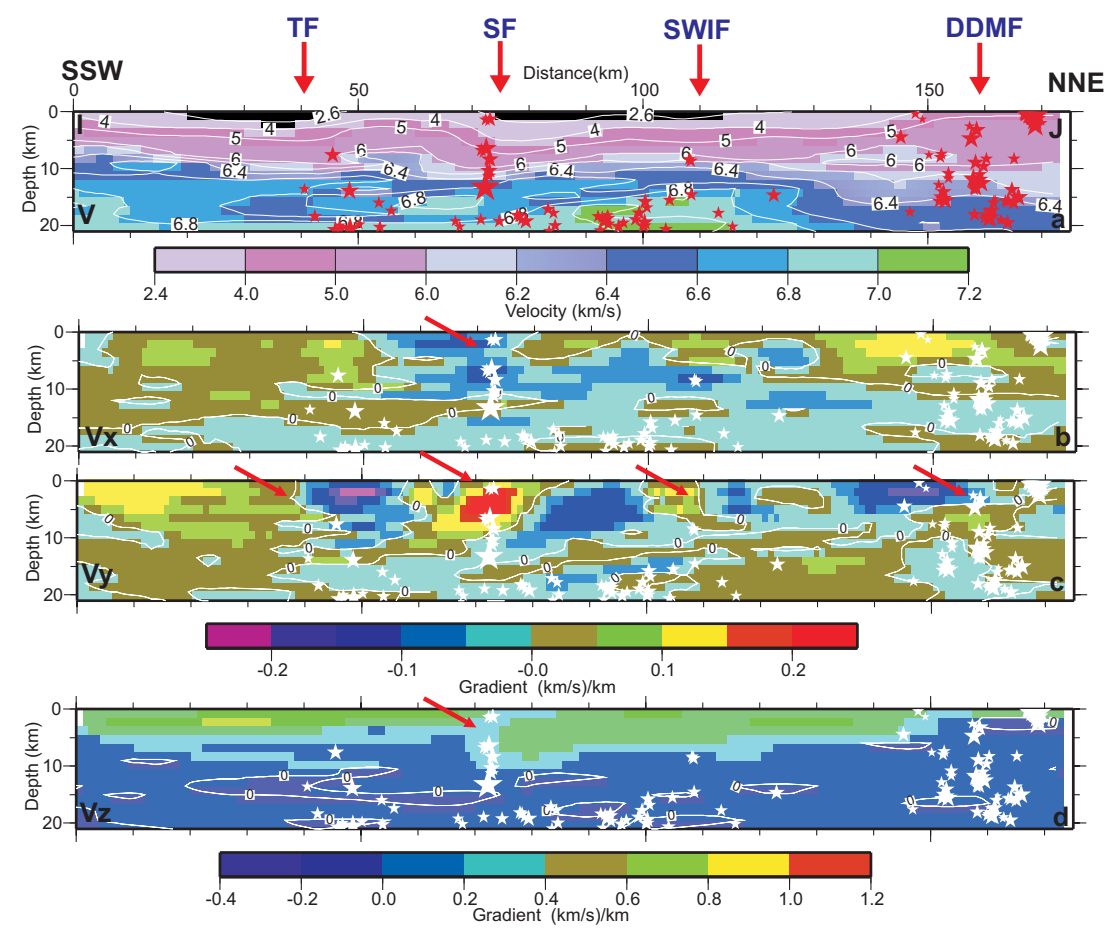

Fig. 6. Profile IJ. Vertical cross-section of (a) tomographic velocity model (b) X gradient of velocity model, (c) Y gradient of velocity model, and (d) $\mathrm{Z}$ gradient of velocity model. Abbreviations as in Fig. 1. 

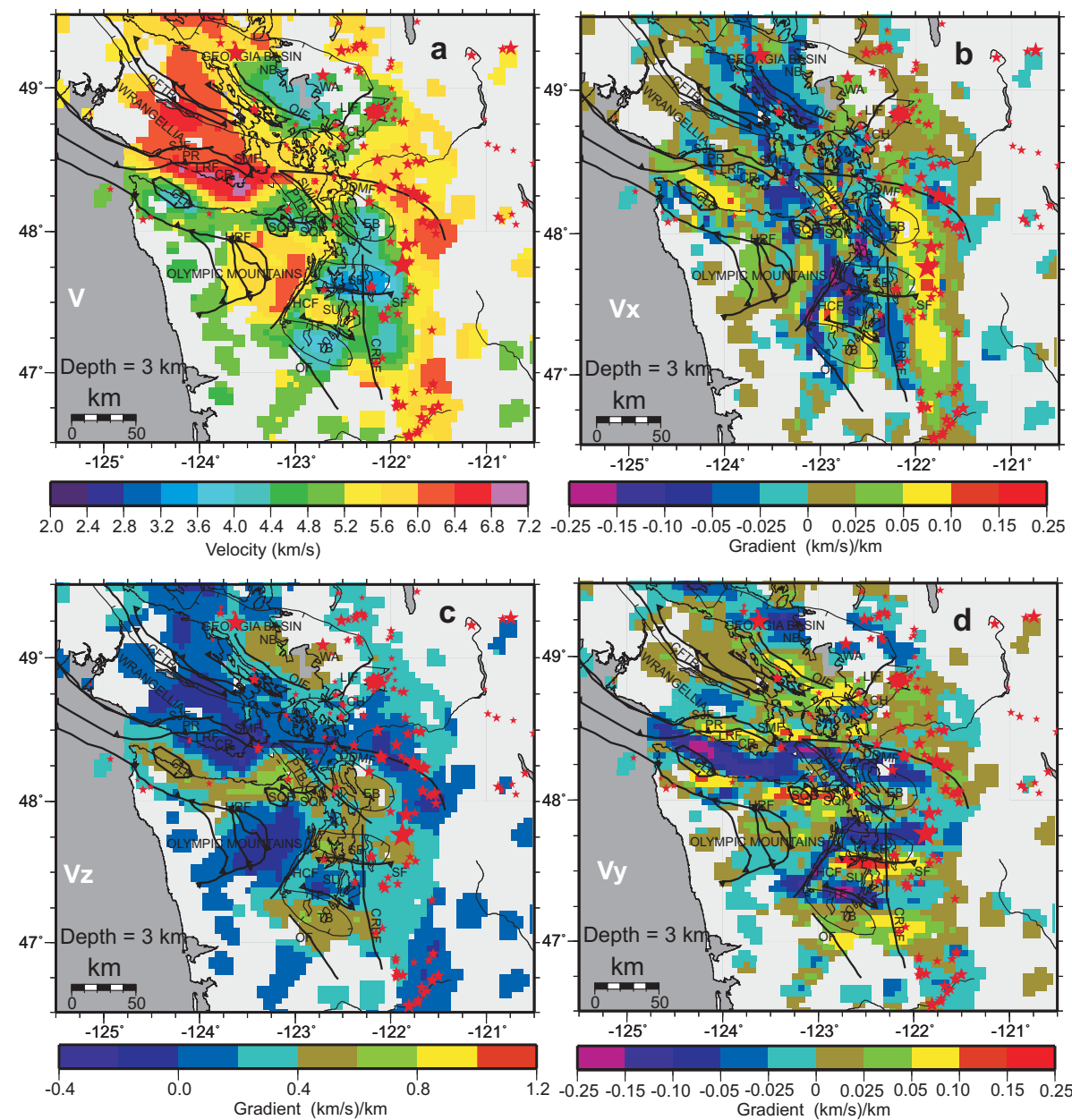

Fig. 7. Horizontal cross-section at $3 \mathrm{~km}$ depth of (a) tomographic velocity model (b) $\mathrm{X}$ gradient of velocity model, (c) Z gradient of velocity model, and (d) Y gradient of velocity model.

\subsection{Tacoma fault}

Based on gravity, a bounding fault on the north side of the Tacoma basin was proposed by Danes et al., (1965). Gower et al. (1985) also proposed this fault based on gravity and aeromagnetic anomalies. Brocher et al. (2001) interpreted this boundary as a north-dipping reverse fault, designated the Tacoma fault (Fig. 1) from a smooth tomographic velocity model and from documented Holocene uplift at two localities north of the Tacoma basin (Bucknam et al., 1992; Sherrod, 1998). This fault is identified on profile IJ (Fig. 6) at $40 \mathrm{~km}$ distance on the $\mathrm{Y}$ and $\mathrm{z}$ gradient plots. From the $\mathrm{Y}$ and $\mathrm{Z}$ gradient values at $20 \mathrm{~km}$ location on this profile, it can be inferred that the basement is approximately at $8 \mathrm{~km}$ depth. In the horizontal slice plot of $\mathrm{Z}$ and $\mathrm{Y}$ gradients (Fig. 7c and d), the fault location correlates with a sharp gradient change in the $\mathrm{N}-\mathrm{S}$ direction.

\subsection{Coast Range Boundary fault}

The Coast Range Boundary fault (CRBF) (Fig. 1) forms the eastern boundary of the Eocene volcanic rocks (Johnson, 1984, 1985; Johnson et al. 1996). CRBF is inferred mainly from tectonic and sedimentologic evidence to lie beneath the eastern Puget Lowland where it strikes approximately N-S (Van Wagoner et al., 2002). Northward motion of the Cascadia forearc region during the early Tertiary may have been accommodated along this right-lateral strike-slip fault, which presumably separates rocks of the Coast Range terrane from the pre-Tertiary basement of the Cascades (Johnson, 1984, 1985; Johnson et al., 1996).

There is no direct evidence for the presence of this fault from the tomographic velocity models constructed by Symons and Crosson (1997), Brocher et al., (2001) Van Wagoner et al., (2002), and Ramachandran et al., (2006). This fault could not be inferred previously from the tomographic velocity models due to the smooth nature of the velocity variations (see top panel of Figs. 4 and 5). However, the CRBF 
can be inferred clearly on profile EF (Fig. 4) at $85 \mathrm{~km} \mathrm{lo-}$ cation on the $\mathrm{X}$ gradient plot and on profile GH (Fig. 5) at $95 \mathrm{~km}$ location on the $X$ gradient plot. In the horizontal slice plot of X gradient (Fig. 7b), the fault location correlates with the gradient change, at a small distance east of the fault.

Johnson et al. (1999) identified a zone of active or potentially active north-trending strike-slip and normal faults, a few kilometers east of and parallel to the Coast Range Boundary fault, representing a portion of a regionally distributed shear zone along which the Washington Coast Range is moving northward relative to the eastern Puget Lowland and Cascade Range. Approximately $10 \mathrm{~km}$ east of the CRBF locations identified on profiles $\mathrm{EF}$ and $\mathrm{GH}$, there is a near vertical line of earthquake locations that correlate with faults paralleling CRBF discussed by Johnson et al. (1999).

\section{Conclusions}

Conventional tomographic velocity model interpretation relies on absolute velocity interpretation or perturbation velocity interpretation. In this study it is shown that spatial gradients of tomographic velocities provide excellent constraints on locating horizontal discontinuities such as faults and basin margins, and vertical discontinuities such as sediment-basement contacts. Even though velocity models possess inherent gradient information, it is not explicitly visible in velocity model plots, making it difficult to interpret geological discontinuities. Application of the velocity gradient interpretation approach to the tomographic velocity model from northern Cascadia resulted in mapping of the significant faults with better clarity. The gradient plots also depict the correlation of some of these faults with seismicity in a much clearer fashion. The Coast Range Boundary fault, which could not previously be mapped from tomographic velocity models, is clearly identifiable in the gradient plots. It is recommended that tomographic velocity model interpretation studies be accompanied by the interpretation of spatial velocity gradients to obtain better structural information about subsurface discontinuities.

Acknowledgements. The author would like to thank The University of Tulsa for providing research support through start up funds. The author is thankful to Lucinda Leonard for critical review and to Habil Ivan Koulakov for providing constructive feedback.

Edited by: H. I. Koulakov

\section{References}

Atwater, B. F. and Moore, A. L.: A tsunami about 1000 years ago in Puget Sound, Washington, Science, 258, 1614-1617, 1992.

Babcock, R. S., Burmester, R. R., Clark, K. P., Engebretson, D. C., and Warnock, A.: A rifted margin origin for the Crescent basalts and related rocks in the northern Coast Range volcanic province,
Washington and British Columbia, J. Geophys. Res., 97, 67996821, 1992.

Blakely, R. J., Wells, R. E., Weaver, C. S., Meagher, K. L., and Ludwin, R.: The bump and grind of Cascadia forearc blocks; evidence from gravity and magnetic anomalies: Geological Society of America Abstracts with Programs, 34, 5, 33, 2002.

Brocher, T. M., Parsons, T., Blakely, R. J., Christensen, N. I., Fisher, M. A., Wells, R. E., and SHIPS Working Group: Upper crustal structure in Puget Lowland, Washington-Results from the 1998 seismic hazards investigation in Puget Sound, J. Geophys. Res., 106, 13541-13564, 2001.

Bucknam, R. C., Hemphill-Haley, E., and Leopold, E. B.: Abrupt uplift within the past 1700 years at southern Puget Sound, Washington, Science, 258, 1611-1614, 1992.

Clowes, R. M., Brandon, M. T., Green, A. G., Yorath, C. J., Brown, A. S., Kanasewich, E. R., and Spencer, C.: LITHOPROBESouthern Vancouver Island: Cenozoic subduction complex imaged by deep seismic-reflections, Can. J. Earth Sci., 24, 31-51, 1987.

Danes, Z. F., Bonno, M. M. , Brau, E., Gilham, W. D., Hoffman, T. F., Johansen, D., Jones, M. H., Malfait, B., Masten, J., and Teague, G. O.: Geophysical investigation of the southern Puget Sound area, Washington, J. Geophys. Res., 70, 5573-5580, 1965.

Dragovich, J. D., Logan, R. L., Schasse, H. W., Walsh, T. J., Lingley, W. S., Norman, D. K., Gerstel, W. J., Lapen, T. J., Schuster, J. E., and Meyers, K. D.: Geologic map of Washington-Northwest quadrant: Washington Division of Geology and Earth Resources Geologic Map GM-50, 72, pamphlet, 3 sheets, scale 1:250,000, 2002.

England, T. D. J., Bustin, R. M.: Architecture of the Georgia Basin, southwestern British Columbia, B. Can. Petrol. Geol., 46, 288320, 1998.

Fishwick, S.: Gradient maps: A tool in the interpretation of tomographic images, Physics of the Earth and Planetary Interiors, 156, 152-157, 2006.

Fisher, M. A., Hyndman, R. D., Johnson, S. Y., Brocher, T. M., Crosson, R. S., Wells, R. E., Calvert, A. J., and ten Brink, U. S.: Crustal Structure and Earthquake Hazards of the Subduction Zone in Southwestern British Columbia and Western Washington, USGS, Professional Paper 1661-C, 2005.

Gower, H. D., Yount, J. C., and Crosson, R. S.: Seismotectonic map of the Puget Sound region, Washington, U.S. Geol. Surv. Misc. Invest. Ser. Map, I-1613, scale 1:250,000, 1985.

Johnson, S. Y.: Evidence for a margin-truncating transcurrent fault (pre-late Eocene) in western Washington, Geology, 12, 538-541, 1984.

Johnson, S. Y.: Eocene strike-slip faulting and nonmarine basin formation in Washington, in Strike-Slip Deformation, Basin formation, and Sedimentation, edited by: Biddle, K. T. and ChristieBlick, N., Spec. Pub. Soc. Econ. Paleon. Mineral., 37, 283-302, 1985.

Johnson, S. Y., Potter, C. J., and Armentrout, J. M.: Origin and evolution of the Seattle fault and Seattle Basin, Washington, Geology, 22, 71-74, 1994.

Johnson, S. Y., Potter, C. J., Armentrout, J. M., Miller, J. J., Finn, C., and Weaver, C. S.: The southern Whidbey Island fault: An active structure in the Puget Lowland, Washington, Geol Soc. Am. Bull., 108, 334-354, 1996.

Johnson, S. Y., Dadisman, S. V., Childs, J. R., and Stanley, W. D.: 
Active tectonics of the Seattle fault and central Puget Sound, Washington-Implications for earthquake hazards, Geol Soc. Am. Bull., 111, 1042-1053, 1999.

Johnson, S. Y., Dadisman, S. V., Mosher, D. C., Blakely, R. J., and Chiles, J. R.: Active tectonics of the Devils Mountain fault and related structures, northern Puget lowland and eastern Strait of Juan de Fuca region, Pacific Northwest, U.S. Geol. Surv. Prof. Pap., 1643, 45, 2 sheets, 2001.

Kelsey, H. M., Sherrod, B., Johnson, S. Y., and Dadisman, S. V.: Land-level changes from a late Holocene earthquake in the northern Puget Lowland, Washington, Geology, 32, 6, 469-472, doi:10.1130/G20361.1, 2004.

Massey, N. W. D.: Metchosin igneous complex, southern Vancouver Island: Ophiolite stratigraphy developed in an emergent island setting, Geology, 14, 602-605, 1986.

Muller, J. E.: Evolution of the Pacific Margin, Vancouver Island, and adjacent regions, Can. J. Earth Sci., 14, 2062-2085, 1977.

Pratt, T. L., Johnson, S., Potter, C., Stephenson, W., and Finn, C.: Seismic reflection images beneath Puget Sound, western Washington state: The Puget Lowland thrust sheet hypothesis, J. Geophys. Res., 102, 27469-27489, 1997.

Ramachandran, K., Dosso, S. E., Spence, G. D., Hyndman, R. D., and Brocher, T. M.: Forearc structure beneath southwestern British Columbia: A three-dimensional tomographic velocity model, J. Geophys. Res., 110, B02303, doi:10.1029/2004JB003258, 2005.
Ramachandran, K., Hyndman, R. D., and Brocher, T. M.: Regional $\mathrm{P}$ wave velocity structure of the Northern Cascadia Subduction Zone, J. Geophys. Res., 111, B12301, doi:10.1029/2005JB004108, 2006.

Sherrod, B. L.: Late Holocene environments and earthquakes in southern Puget Sound, Ph.D. thesis, 159 pp., Univ. of Wash., 1998.

Sherrod, B. L., Blakely, R. J., Weaver, C. S., Kelsey, H. M., Barnett, E., Liberty, L., Meagher, K. L., and Pape, K.: Finding concealed active faults: Extending the southern Whidbey Island fault across the Puget Lowland, Washington, J. Geophys. Res., 113, B05313, doi:10.1029/2007JB005060, 2008.

Symons, N. P. and Crosson, R. S.: Seismic velocity structure of the Puget Sound region from 3-D non-linear tomography, Geophys. Res. Lett., 24, 2593-2596, 1997.

Van Wagoner, T. M., Crosson, R. S., Creager, K. C., Medema, G., Preston, L., Symons, N. P., and Brocher, T. M.: Crustal structure and relocated earthquakes in the Puget Lowland, Washington, from high-resolution seismic tomography, J. Geophys. Res., 107, 2381, doi:10.1029/2001JB000710, 2002.

Wells, R. E., Weaver, C. S., and Blakely, R. J.: Fore-arc migration in Cascadia and its neotectonic significance, Geology, 26, 759-762, 1998. 